\title{
Uptake and Utilization of Acetate by Mycoplasma
}

\author{
By S. ROTTEM AND S. RAZIN \\ Department of Clinical Microbiology, Hebrew University-Hadassah Medical School, \\ Jerusalem, Israel
}

(Accepted for publication 11 February 1967)

SUMMARY

\begin{abstract}
Mycoplasma laidlawii and M. gallisepticum were found to incorporate $\left[{ }^{14} \mathrm{C}\right]$ acetate from the growth medium mainly into their polar lipids, whereas $M$. hominis and $M$. orale incorporated the acetate mainly into their neutral lipids. M. mycoides var. mycoides, Mycoplasma sp. strain 14 and $M$. fermentans did not incorporate acetate, although they were found to possess acetokinase activity. Most of the radioactivity of incorporated acetate was found in the fatty acid fraction of $M$. laidlawii lipids. Palmitic and stearic acids almost completely inhibited acetate incorporation by this organism, whereas oleic acid did not, indicating that the major part of the acetate incorporated by $M$. laidlawii was used for the synthesis of saturated fatty acids. Washed $M$. laidlawii required glucose, coenzyme $\mathrm{A}(\mathrm{CoA})$ and $\mathbf{M g}^{2+}$ for acetate uptake. The uptake process was temperature-dependent and $\mathrm{pH}-$ dependent and was inhibited by several metabolic inhibitors, in particular iodoacetate. Pyruvate considerably enhanced acetate incorporation into $M$. laidlawii lipids without raising the low degree of radioactivity in the cell fraction soluble in cold trichloroacetic acid. Pyruvate did not replace glucose as an energy source for acetate uptake. Propionate and butyrate markedly decreased the acetate uptake, probably by inhibition of the acetokinase activity of the organisms.
\end{abstract}

\section{INTRODUCTION}

Lipids form an essential part of the cell membrane of Mycoplasma organisms. The ability of the mycoplasmas to synthesize membrane lipids is restricted and several lipids and lipid precursors, essential for membrane structure and function, have to be supplied exogenously (Smith, 1964; Razin, 1967). In view of the importance of acetate as a lipid precursor it seemed worth while to study the conditions which govern its transport into the Mycoplasma organisms and its incorporation into cell lipids. There is clear evidence about the utilization of acetate for carotenoid synthesis in $\mathbf{M}$. laidlawii (Smith, 1963). More recently, Smith \& Henrikson (1965) showed the existence of a biosynthetic pathway leading from acetate to mevalonic acid in two Mycoplasma strains. Phosphorylation of acetate, a preliminary step in its utilization for lipid biosynthesis, has been shown to occur in several Mycoplasma strains (Castrejon-Diez, Fisher \& Fisher, 1962).

\section{METHODS}

Organisms. Mycoplasma laidlawii (oral strain), serologically related to $M$. laidlawii strain A, was isolated in our laboratory from the human oral cavity. $M$. gallisepticum strain A 5969 was obtained from Dr M. E. Tourtellotte (Department of Animal Diseases, 
University of Connecticut, Storrs). M. mycoides var. mycoides (PG 1) was provided by Dr D. G. ff. Edward (The Wellcome Research Laboratories, Beckenham, Kent) and Mycoplasma sp. strain 14 (goat strain) was originally supplied by Dr H. E. Adler (School of Veterinary Medicine, University of California, Davis, U.S.A.). M. hominis type 1, strain H 34 (ATCC 15056), M. fermentans strain GII (ATCC 15474) and M. orale strain 823 B (ATCC15539) were obtained from the American Type Culture Collection (Rockville, Md., U.S.A.).

Growth conditions. Growth of organisms was usually done in $500 \mathrm{ml}$. volumes of a modified Edward medium (Razin, 1963) dispensed in 11. flasks. In some experiments uniformly labelled $\left[{ }^{14} \mathrm{C}\right]$ sodium acetate (specific activity $15.7 \mathrm{mc} . / \mathrm{m}$-mole) or uniformly labelled $\left[{ }^{14} \mathrm{C}\right]$ sodium pyruvate (specific activity $6.5 \mathrm{mc} . / \mathrm{m}$-mole) purchased from the Radiochemical Centre, Amersham, England, was added to the growth medium in amounts of $1 \mu \mathrm{c} . / 100 \mathrm{ml}$. medium. Unlabelled acetate or pyruvate was added to the growth medium to a final concentration of $2 \times 10^{-3} \mathrm{M}$. The organisms were harvested after incubation for $16-24 \mathrm{hr}$ at $37^{\circ}$ by centrifugation at $15,000 \mathrm{~g}$ for $15 \mathrm{~min}$. The packed organisms were washed twice in $0.25 \mathrm{M}-\mathrm{NaCl}$ containing $0.01 \mathrm{M}$ $\mathrm{MgCl}_{2}$. Cell membranes were separated from the 'soluble' fraction after osmotic lysis of the washed organisms (Razin \& Cleverdon, 1965).

Extraction and fractionation of cell lipids. Washed packed organisms were extracted with chloroform + methanol $(2+1$, by vol. $)$ at $50^{\circ}$ for $30 \mathrm{~min}$. The extract was separated from the insoluble residue by filtration through filter paper previously extracted with chloroform + methanol. The solvent was evaporated to dryness by heating under a stream of nitrogen, and the lipid residue was redissolved in 1-2 ml. chloroform. This solution was applied to a $7 \times 95 \mathrm{~mm}$. column of activated silicic acid (100 mesh, Mallinckrodt Chemical Works, St Louis, Mo., U.S.A.) pre-washed with chloroform. Neutral lipids were eluted from the column with $7 \mathrm{ml}$. chloroform, by the use of positive pressure. The polar lipids were then eluted with $7 \mathrm{ml}$. methanol (Ansell \& Hawthorne, 1964). Methanolysis of lipids was done by the method of Kates (1964). The lipids extracted from the organisms according to Folch, Lees \& Sloane-Stanley (1957) were hydrolyzed in methanolic hydrogen chloride solution, and the resulting fatty acid methyl esters were extracted with light petroleum.

Incorporation of acetate by washed organisms. Reaction mixtures (total vol. $1.0 \mathrm{ml}$.) contained $0.5 \mathrm{ml}$. of a suspension of washed organisms (1.0-1.2 mg. cell protein) in 0.4 M-sucrose containing $0.05 \mathrm{M}$-phosphate buffer ( $\mathrm{pH} \mathrm{8.0),} 5 \mu$ moles $\mathrm{MgCl}_{2}, 20$ $\mu$ moles glucose and $5 \mu \mathrm{g}$. CoA. The reaction mixtures were incubated at $37^{\circ}$ for $10 \mathrm{~min}$. and $1 \mu$ mole of sodium acetate and $0.02 \mu \mathrm{c}$ of $\left[{ }^{14} \mathrm{C}\right]$ sodium acetate then added to each test-tube. After further incubation for $30 \mathrm{~min}$. acetate incorporation was stopped by addition of $3 \mathrm{ml}$. of ice-cold sucrose + phosphate buffer and immediate centrifugation at $25,000 \mathrm{~g}$ for $10 \mathrm{~min}$. The sedimented organisms were washed once with $4 \mathrm{ml}$. of sucrose phosphate buffer and the pellet lysed in $0.5 \mathrm{ml}$. of $0.02 \mathrm{M}$-sodium laurylsulphate. For the determination of 'free' and 'bound' acetate in the organisms $4 \mathrm{ml}$. ice-cold $12.5 \%(\mathrm{w} / \mathrm{v})$ trichloroacetic acid (TCA) were added to the reaction mixture at the end of the incubation period. The test-tubes were kept in an ice-bath for $30 \mathrm{~min}$. and then centrifuged at $4^{\circ}$. The precipitates were washed with $5 \mathrm{ml}$. ice-cold $10 \%$ (w/v) TCA and resuspended in 0.02 M-sodium laurylsulphate. Samples of the materials dissolved in sodium laurylsulphate were taken for radioactivity measurement.

Radioactivity measurement. Samples $(0 \cdot 25-0.30 \mathrm{ml}$.) of lysed organisms or membranes 
were transferred to scintillation vials. Eight $\mathrm{ml}$. of $0.7 \% 2,5$-diphenyloxazole (PPO, scintillation grade), 0.005\% 1,4-bis-2(5-phenyl-oxazolyl)-benzene (POPOP, scintillation grade, Packard Instrument Co., Inc., Illinois, U.S.A.) and $5 \%$ (w/v) naphthalene in dioxane were added to each vial, followed by addition of $1.5 \mathrm{ml} .0 .3 \%$ PPO and $0.01 \%$ POPOP in toluene. Lipid extracts were placed in the scintillation vials and evaporated by heating under a stream of air and scintillation liquid added as above. ${ }^{14} \mathrm{C}$-counting was done in a Packard liquid scintillation counter.

Analytical methods. Protein in cell fractions was determined according to Lowry, Rosebrough, Farr \& Randall (1951). Acetokinase activity in suspensions of disrupted organisms was determined according to Rose (1955) by measuring hydroxamic acid formed from acetate in the presence of hydroxylamine under acid conditions. Organisms were disrupted by treatment of their suspensions in the M.S.E. ultrasonic disintegrator ( $60 \mathrm{~W}$., $20 \mathrm{kc}$.) for $2.5 \mathrm{~min}$. Phosphotransacetylase in disrupted suspensions was measured according to Stadtman (1955).

Chemicals. Lauric acid $(99 \%+$, pure), palmitic acid $(99 \%+$, pure), stearic acid ( $99 \%+$, pure), oleic acid ( $99 \%+$, pure), and thiamine pyrophosphate were the products of Nutritional Biochemicals Corporation (Cleveland, Ohio, U.S.A.). The fatty acids were added to the growth medium in ethanolic solution. Coenzyme A, grade I was purchased from Sigma Chemical Co. (St Louis, Mo., U.S.A.).

\section{RESULTS}

Incorporation of acetate by various Mycoplasma strains

Of the seven Mycoplasma strains included in the present study only four incorporated acetate from the growth medium (Table 1). Acetate was incorporated mainly into lipids located in the cell membrane. The larger part of the incorporated acetate

Table 1. Incorporation of $\left[{ }^{14}\right.$ C $]$ acetate by growing Mycoplasma organisms

\begin{tabular}{|c|c|c|c|c|c|}
\hline \multirow[b]{2}{*}{ Strain } & \multirow[b]{2}{*}{$\begin{array}{l}\text { Yield of } \\
\text { organisms } \\
\text { (mg. } \\
\text { protein) }\end{array}$} & \multicolumn{4}{|c|}{ Radioactivity (counts/min.) } \\
\hline & & $\begin{array}{l}\text { Whole } \\
\text { organisms }\end{array}$ & $\begin{array}{l}\text { Total } \\
\text { lipid }\end{array}$ & $\begin{array}{l}\text { Neutral } \\
\text { lipid } \\
\text { fraction }\end{array}$ & $\begin{array}{l}\text { Polar } \\
\text { lipid } \\
\text { fraction }\end{array}$ \\
\hline M. laidlawii & $25 \cdot 0$ & 55,000 & 46,300 & 1,900 & 42,100 \\
\hline M. gallisepticum & $13 \cdot 7$ & 8,850 & 7,246 & 870 & 5,860 \\
\hline M. hominis & $4 \cdot 2$ & 2,480 & 2,180 & 1,255 & 864 \\
\hline M. orale & $5 \cdot 1$ & 3,650 & 3,590 & 2,000 & 1,255 \\
\hline M. fermentans & $7 \cdot 5$ & 204 & 126 & 11 & 37 \\
\hline M. mycoides var. mycoides & $20 \cdot 5$ & 260 & 46 & 0 & 0 \\
\hline Mycoplasma sp. strain 14 & $25 \cdot 0$ & 290 & 34 & 0 & 0 \\
\hline
\end{tabular}

Organisms were grown in 200 $\mathrm{ml}$. Edward medium containing $2 \%$ (v/v) PPLO-serum fraction and $2 \mu \mathrm{c}$ of $\left[{ }^{14} \mathrm{C}\right]$ acetate.

was found in the polar lipids of Mycoplasma laidlawii and $M$. gallisepticum and in the neutral lipids of $M$. hominis and $M$. orale. Methanolysis of the polar lipids of $M$. laidlawii showed the label derived from radioactive acetate to be confined to the fatty acid methyl esters. $M$. laidlawii incorporated appreciably more acetate than the other strains. Therefore most of the subsequent experiments were done with this strain. 
Conditions influencing acetate incorporation by washed organisms

Washed cells of Mycoplasma laidlawii incorporated acetate when suspended in buffer containing glucose, CoA and magnesium ions (Table 2). Glucose, apparently serving as an energy source, could not be replaced by pyruvate $(20 \mu \mathrm{moles} / \mathrm{ml}$.) or by adenosine triphosphate $(10 \mu \mathrm{moles} / \mathrm{ml}$.). The requirement for CoA was more pronounced with twice-washed organisms than with organisms washed only once (Table 2). Exogenous thiamine pyrophosphate was not required for acetate uptake.

Acetate incorporation by the organisms was temperature-dependent and $\mathrm{pH}$ dependent. No incorporation took place below $15^{\circ}$ or above $45^{\circ}$. Incorporation was best at $30-37^{\circ}$ and at $\mathrm{pH} 8 \cdot 3$ (Fig. 1). The uptake of acetate was highest with organisms harvested at the early logarithmic phase of growth. At later growth phases the capacity of the cells to incorporate acetate declined steeply.

\section{Table 2. Requirement of glucose, coenzyme $A$ and magnesium for acetate incorporation by washed Mycoplasma laidlawii}

The complete reaction mixture contained $0.5 \mathrm{ml}$ washed organisms (equiv. $1.2 \mathrm{mg}$. cell protein) suspended in $0.4 \mathrm{M}$-sucrose containing $0.05 \mathrm{M}$-phosphate buffer (pH 8.0); $20 \mu$ moles glucose, $5 \mu$ moles $\mathrm{MgCl}_{2} ; 5 \mu \mathrm{g}$. CoA; $1 \mu$ mole sodium acetate; $0.02 \mu \mathrm{c}$ [ ${ }^{14} \mathrm{C}$ ]acetate in total volume $1 \mathrm{ml}$.

Acetate incorporation

$\begin{array}{lc}\text { Reaction mixture } & \text { (counts/min./mg. cell protein) } \\ \text { Complete } & 1020 \\ \text { Without glucose } & 40 \\ \text { Without CoA } & 264 \\ & 612^{*} \\ \begin{array}{l}\text { Without magnesium } \\ \text { chloride }\end{array} & 480\end{array}$

* Organisms washed only once.

\section{'Free' and 'bound' acetate}

The acetate taken up by the washed organisms was rapidly incorporated into compounds non-extractable with cold $10 \%$ (w/v) TCA ('bound acetate'). The amount of radioactivity extractable with cold TCA ('free acetate') did not exceed 10-20\% of the total radioactivity incorporated by the organisms throughout the reaction period, when the external concentration of acetate was $1 \times 10^{-3} \mathrm{M}$. Under these conditions acetate incorporation reached completion after incubation for 25-30 min. (Fig. 2). The amount of acetate incorporated into the TCA-extractable fraction was dependent on the external concentration of acetate and followed a typical saturation curve (Fig. 3).

\section{Effect of metabolic inhibitors on acetate uptake}

Ethylenediaminetetraacetic (EDTA) acid $\left(1 \times 10^{-2} \mathrm{M}\right)$ completely inhibited acetate incorporation by washed Mycoplasma laidlawii organisms, apparently by chelation of the magnesium ions required for the reaction. Thallous sulphate $\left(2 \times 10^{-3} \mathrm{M}\right)$ inhibited the incorporation of acetate by about $40 \%$. Table 3 shows that acetate incorporation by $M$. laidlawii was strongly inhibited by sodium iodoacetate, at a concentration as low as $1 \times 10^{-5} \mathrm{M}$. Sodium arsenate, sodium fluoride and $p$-chloromercuribenzoate were 
also inhibitory, but to a smaller degree. Sodium azide $\left(1 \times 10^{-3} \mathrm{M}\right)$, potassium cyanide $\left(1 \times 10^{-3} \mathrm{M}\right)$, and ouabain $\left(1 \times 10^{-3} \mathrm{M}\right)$ did not affect acetate uptake by washed $M$. laidlawii organisms.

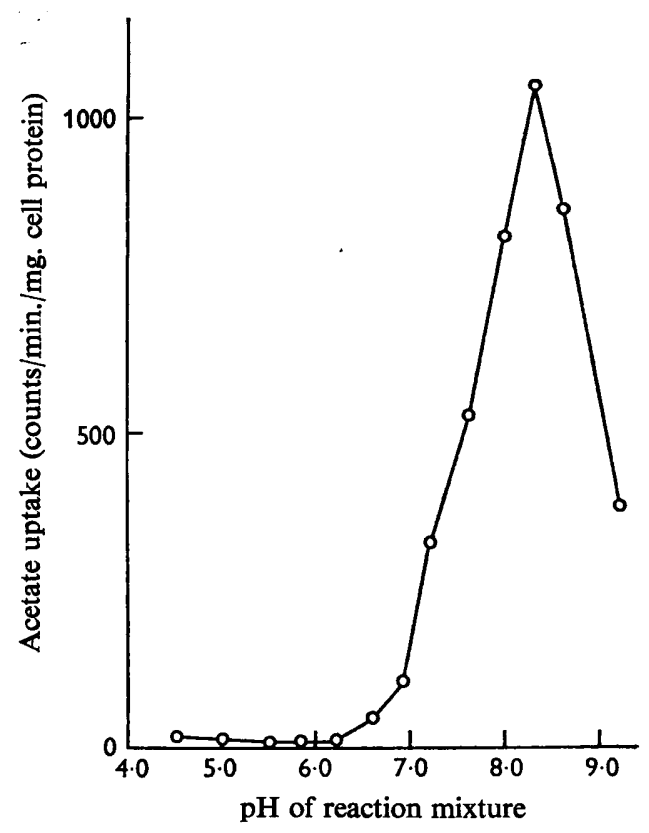

Fig. 1

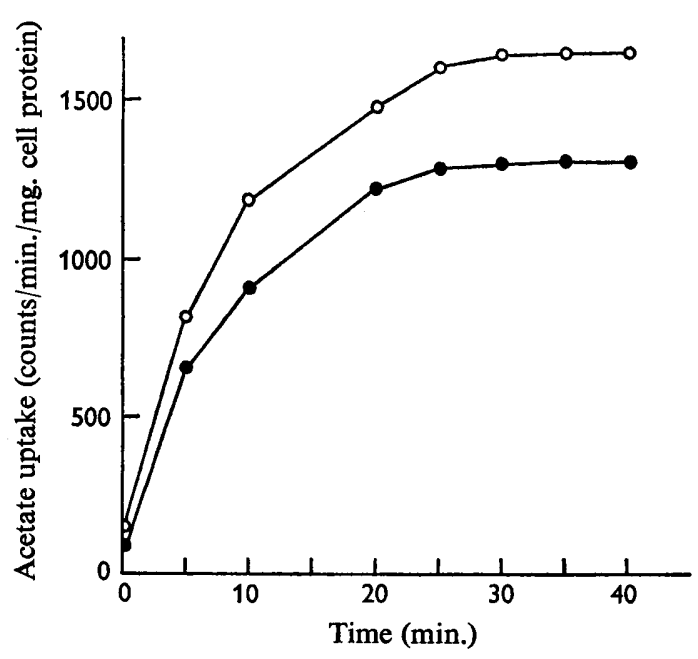

Fig. 2

Fig. 1. Effect of pH value on acetate uptake by washed Mycoplasma laidlawii.

Fig. 2. Uptake of $\left[{ }^{14} \mathrm{C}\right]$ acetate by washed Mycoplasma laidlawii. $\mathrm{O}$, Total radioactivity in organisms; - , radioactivity in the cold TCA-insoluble fraction of organisms.

Table 3. Inhibitors of acetate uptake by washed Mycoplasma laidlawii

The reaction mixtures were as in Table 2 . The inhibitors were added to the reaction mixtures $20 \mathrm{~min}$. before the addition of acetate.

$\begin{array}{lccc}\text { Inhibitor } & \begin{array}{c}\text { Concentration } \\ \text { of inhibitor } \\ (\mathbf{M})\end{array} & \begin{array}{c}\text { Counts/min./mg. } \\ \text { cell protein }\end{array} & \begin{array}{c}\text { Inhibition* } \\ (\%)\end{array} \\ \text { No inhibitor } & - & 1646 & 0 \\ \text { Sodium iodoacetate } & 1 \times 10^{-4} & 16 & 99 \\ \text { Sodium arsenate } & 1 \times 10^{-5} & 250 & 85 \\ & 1 \times 10^{-2} & 348 & 79 \\ \text { Sodium fluoride } & 1 \times 10^{-3} & 1450 & 12 \\ & 1 \times 10^{-4} & 1650 & 0 \\ p \text {-Chloromercuribenzoate } & 1 \times 10^{-3} & 480 & 71 \\ & 1 \times 10^{-4} & 1160 & 30 \\ & 1 \times 10^{-5} & 1450 & 12 \\ & 1 \times 10^{-3} & 49 & 97 \\ & 1 \times 10^{-4} & 1402 & 15\end{array}$

* Compared to control without inhibitor. 


\section{Effect of structurally related organic acids on acetate uptake}

To test the specificity of the acetate incorporation system, several organic acids which structurally resemble acetate were added to the reaction mixtures at a concentration ten times greater than that of acetate. Sodium propionate and butyrate inhibited acetate uptake, whereas sodium pyruvate enhanced it (Table 4). Sodium formate, lactate and oxaloacetate were without effect on acetate incorporation. The

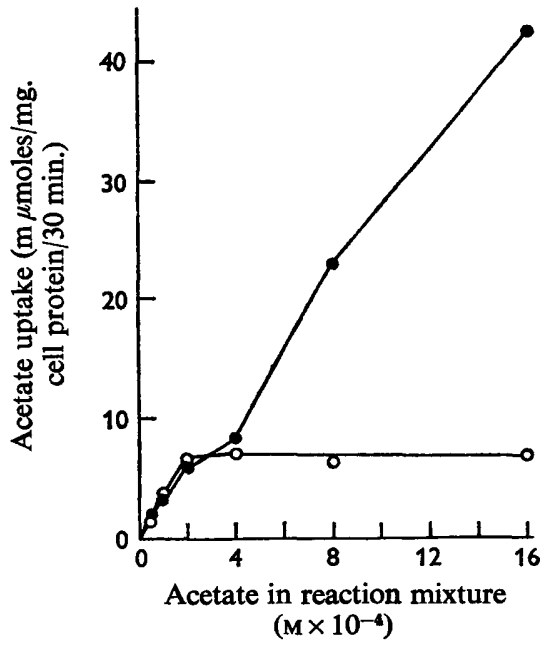

Fig. 3

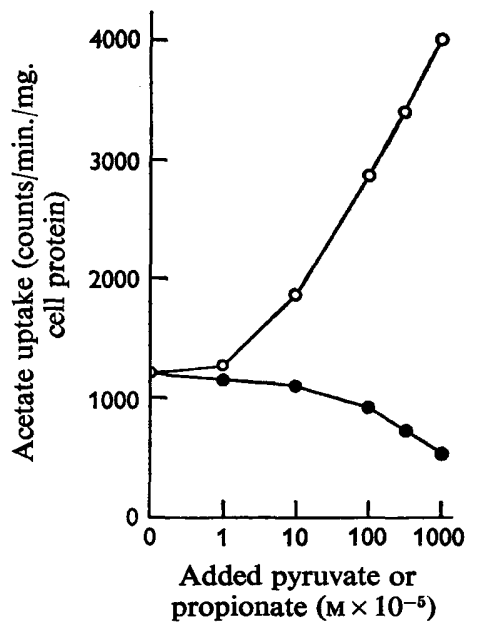

Fig. 4

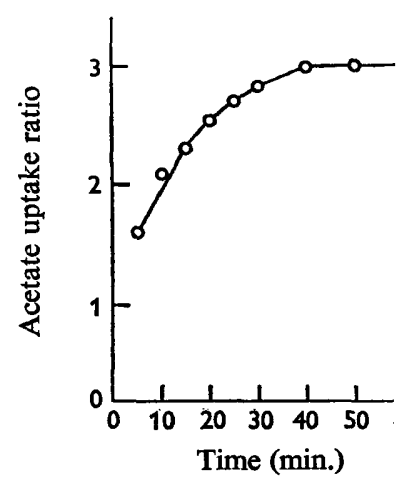

Fig. 5

Fig. 3. Distribution of acetate incorporated by Mycoplasma laidlawii between the cold TCAsoluble fraction $(O)$ and cold TCA-insoluble fraction of organisms (O).

Fig. 4. Effect of sodium pyruvate $(O)$ and sodium propionate $(0)$ on the uptake of acetate by washed Mycoplasma laidlawii. The concentration of acetate in the reaction mixtures was $1 \times 10^{-8} \mathrm{M}$.

Fig. 5. Enhancement of acetate uptake by pyruvate as a function of time. Mycoplasma laidlawii organisms were incubated with $1 \times 10^{-3} \mathrm{M}$ sodium acetate together with or without $1 \times 10^{-2} \mathrm{M}$-sodium pyruvate. Results are expressed as the ratio between $\left[{ }^{14} \mathrm{C}\right]$ acetate incorporated in the presence and in the absence of pyruvate.

Table 4. Effect of structurally related organic acids on the uptake of $\left.{ }^{[14} \mathrm{C}\right]$ acetate by washed Mycoplasma laidlawii

The reaction mixtures were as in Table 2.

Organic acid

Control

Sodium formate

Sodium propionate

Sodium butyrate

Sodium pyruvate

Sodium lactate

Sodium oxaloacetate
Acetate incorporation (counts/min./mg. Incorporation* cell protein) (\%)

$\begin{array}{rr}2568 & 100 \\ 2520 & 98 \\ 550 & 21 \\ 1146 & 44 \\ 3750 & 145 \\ 2712 & 106 \\ 2680 & 104\end{array}$

* Compared to a control containing $1 \times 10^{-3} \mathrm{M}$ sodium acetate alone. 
inhibitory effect of propionate as well as the stimulatory effect of pyruvate depended on the concentration of these acids (see Fig. 4).

The stimulatory effect of pyruvate was more pronounced when the organisms were incubated with it before the acetate was added. The degree of enhancement by pyruvate increased with time (Fig. 5). Fractionation of the organisms with cold $10 \%$ (w/v) TCA showed that pyruvate increased the amount of acetate incorporated into the TCA-insoluble fraction, while it had no effect on the amount of 'free' acetate found in the TCA-soluble fraction (Table 5). Pyruvate did not replace glucose as an

Table 5. Effect of pyruvate on the incorporation of acetate into TCA-insoluble and TCA-soluble fractions of washed Mycoplasma laidlawii

The reaction mixtures were as in Table 2.

$\mathrm{m} \mu$ moles acetate incorporated $/ \mathrm{mg}$. cell protein $/ 30 \mathrm{~min}$.

\begin{tabular}{|c|c|c|c|c|}
\hline \multirow[b]{2}{*}{ Acetate (M) } & \multicolumn{2}{|c|}{ TCA-insoluble fraction } & \multicolumn{2}{|c|}{ TCA-soluble fraction } \\
\hline & No pyruvate & With pyruvate* & No pyruvate & With pyruvate* \\
\hline $\begin{array}{l}5 \times 10^{-5} \\
1 \times 10^{-4} \\
2 \times 10^{-4} \\
4 \times 10^{-4}\end{array}$ & $\begin{array}{l}0.87 \\
1.92 \\
4 \cdot 70 \\
9 \cdot 30\end{array}$ & $\begin{array}{r}2 \cdot 70 \\
4 \cdot 95 \\
9 \cdot 20 \\
16 \cdot 20\end{array}$ & $\begin{array}{l}0.12 \\
0.22 \\
0.48 \\
0.52\end{array}$ & $\begin{array}{l}0.17 \\
0.22 \\
0.44 \\
0.43\end{array}$ \\
\hline
\end{tabular}

Table 6. Incorporation of $\left[{ }^{14} \mathrm{C}\right]$ acetate and $\left[{ }^{14} \mathrm{C}\right]$ pyruvate by growing Mycoplasma laidlawii

Organisms were grown in $200 \mathrm{ml}$. of Edward medium containing 1\% (v/v) PPLO-serum fraction and $2 \mu \mathrm{c}$. of $\left[{ }^{14} \mathrm{C}\right]$ acetate or $\left[{ }^{14} \mathrm{C}\right]$ pyruvate

\begin{tabular}{|c|c|c|c|c|}
\hline \multirow[b]{3}{*}{ Growth medium containing: } & \multirow[b]{3}{*}{$\begin{array}{c}\text { Yield of } \\
\text { organisms } \\
\text { (mg. protein) }\end{array}$} & \multicolumn{3}{|c|}{ Radioactivity (counts/min.) } \\
\hline & & \multirow[b]{2}{*}{$\begin{array}{l}\text { Whole } \\
\text { organisms }\end{array}$} & \multicolumn{2}{|c|}{ Lipid fraction } \\
\hline & & & $\begin{array}{l}\text { Polar lipid } \\
\text { fraction }\end{array}$ & $\begin{array}{l}\text { Neutral lipid } \\
\text { fraction }\end{array}$ \\
\hline$\left[{ }^{14} \mathrm{C}\right]$ Sodium acetate & $22 \cdot 5$ & 22,200 & 18,200 & 450 \\
\hline$\left[{ }^{14} \mathrm{C}\right]$ Sodium pyruvate & $25 \cdot 7$ & 4,200 & 3,480 & 40 \\
\hline
\end{tabular}

energy source required for acetate incorporation by washed organisms, neither could it support the growth of Mycoplasma laidlawii when glucose was omitted from Edward medium. However, labelled pyruvate was incorporated by growing or washed $M$. laidlawii to $10-20 \%$ of that of acetate incorporated under the same conditions. Most of the radioactivity derived from pyruvate was detected in the polar lipids of the organisms (Table 6). Methanolysis of these lipids showed the label to be confined to the fatty acid methyl esters.

\section{Repression of acetate incorporation by long-chain fatty acids}

The finding that acetate was incorporated mainly into the polar lipids of $\mathrm{Myco}$ plasma laidlawii indicated its use for the biosynthesis of long-chain fatty acids. Addition of palmitic and stearic acids to the growth medium almost completely inhibited acetate incorporation. Oleic acid had no effect on acetate uptake (Table 7). 


\section{Inhibition of acetokinase activity of Mycoplasma laidlawii \\ by short-chain fatty acids}

Acetokinase activity was observed in all the strains included in this study (Table 8), a finding which amplifies the previous reports of Castrejon-Diez et al. (1962) and Smith \& Henrikson (1965). Acetokinase activity of Mycoplasma laidlawii was local-

\section{Table 7. Inhibition of acetate incorporation into lipids of Mycoplasma laidawii by long-chain fatty acids}

Organisms were grown in $100 \mathrm{ml}$. Edward medium containing $1 \%$ (v/v) PPLO-serum fraction and $1 \mu \mathrm{c}$. of $\left[{ }^{14} \mathrm{C}\right]$ acetate. The fatty acids were added to the medium to a final concentration of $5 \mu \mathrm{g} . / \mathrm{ml}$.

Fatty acid added

None

Palmitic acid

Stearic acid

Stearic acid + palmitic acid

Oleic acid

Lauric acid
Cell yield
(mg. protein)

$11 \cdot 0$

$11 \cdot 6$

$8 \cdot 3$

$10 \cdot 2$

$11 \cdot 3$

$9 \cdot 5$
Radioactivity in lipid fraction (counts/min.)

Table 8. Acetokinase activity of several Mycoplasma strains

Each tube contained $50 \mu$ moles of Tris buffer (pH 7.4), $250 \mu$ moles sodium acetate, $10 \mu$ moles $\mathrm{MgCl}_{2}, 700 \mu$ moles neutralized hydroxylamine, $10 \mu$ moles ATP, equiv. $1 \mathrm{mg}$. cell protein, in a total volume of $1.0 \mathrm{ml}$. Reaction time was $2 \mathrm{~min}$. at $37^{\circ}$.

Acetokinase activity ( $\mu$ moles hydroxamic acid formed/mg. protein/min.)

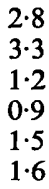

Table 9. Acetokinase activity of Mycoplasma laidlawii

The reaction mixtures were as in Table 8, except for the fatty acid.

Substrate (m-mole)

Acetate (0.12)

Propionate $(0 \cdot 12)$

Butyrate $(0 \cdot 12)$

Pyruvate $(0 \cdot 12)$

Acetate $(0 \cdot 12)+$ propionate $(0 \cdot 12)$

+ propionate $(0.60)$

+ propionate $(1 \cdot 20)$

+ butyrate $(0 \cdot 12)$

+ butyrate $(0.60)$

+ pyruvate $(0.60)$
Acetokinase activity ( $\mu$ moles hydroxamic acid formed/mg. protein/min.) 
ized in the 'soluble' fraction of the cells. Propionate and butyrate did not replace acetate as substrates for this reaction. Furthermore, both acids markedly inhibited the phosphorylation of acetate. Pyruvate had no effect on this enzymic activity (Table 9). Propionate and butyrate did not inhibit phosphotransacetylase activity of M. laidlawii.

\section{DISCUSSION}

Only some of the Mycoplasma strains included in the present study were capable of acetate incorporation. In those strains which incorporated radioactive acetate the label was found almost entirely in the cell lipids. Mycoplasma laidlawii incorporated over $90 \%$ of the label into its polar lipids. Hence, incorporation into carotenoids represented only a minor fraction of its total acetate uptake. We have good reasons to believe that acetate is used by $M$. laidlawii mainly for the biosynthesis of saturated long-chain fatty acids. This assumption is based on previous nutritional findings that $M$. laidlawii does not require saturated fatty acids for growth (Razin \& Rottem, 1963) and on the present finding that palmitic and stearic acids almost completely inhibit acetate uptake, apparently by a mechanism of end-product inhibition. The Mycoplasma strains which were found incapable of acetate incorporation, such as M. mycoides var. mycoides and the goat Mycoplasma are known to require both saturated and unsaturated fatty acids for growth, in addition to glycerol and cholesterol (Rodwell \& Abbot, 1961; Rodwell, 1967). Nevertheless, these strains were found to possess acetokinase activity, suggesting a block in fatty acid and sterol synthesis further up in the biosynthetic pathways, or the absence of an acetate transport system.

Acetate uptake and utilization by the mycoplasmas decreased very steeply with the ageing of the cultures. The same was previously described in respect of the nucleolytic (Razin, Knyszynski \& Lifshitz, 1964) lipolytic (Rottem \& Razin, 1964) and adenosine triphosphatase (ATPase) activity (Rottem \& Razin, 1966) of mycoplasmas. Leakage of enzymes and co-factors from ageing organisms seems to be the most likely explanation for the unusually rapid decline in enzymic activity. The marked tendency of mycoplasmas to swell and lyse in aged cultures (Freundt, 1958; Razin \& Cosenza, 1966) supports this assumption.

Washed Mycoplasma laidlawii organisms required CoA for acetate incorporation. This requirement was more pronounced when the organisms were washed several times, demonstrating the marked tendency of mycoplasmas to lose co-factors on washing (Neimark \& Pickett, 1960; Razin \& Cohen, 1963). CoA was found to be required for growth of $M$. laidlawii in a defined medium (Tourtellotte, Morowitz \& Kasimer, 1964).

The acetate taken up by the organisms was very rapidly incorporated into cold TCA-insoluble compounds. The portion of label derived from acetate in the cold TCA-extractable fraction was consistently small. Pyruvate considerably enhanced acetate incorporation into cell lipids without increasing the amount of 'free acetate' in the TCA-extractable fraction. No explanation for the pyruvate effect has yet been found. Pyruvate did not replace glucose as an energy source, either in the acetate incorporation system, or in the growth medium of Mycoplasma laidlawii. The observation that the stimulatory effect of pyruvate increased with time (Fig. 5) and was more pronounced when pyruvate was pre-incubated with the organisms can be explained by the time required for the organisms to transform pyruvate to an active precursor 
for lipid biosynthesis. The possibility that this precursor is $\alpha$-glycerophosphate was brought up when White \& Klein (1966) showed this compound to stimulate acetate incorporation into fatty acids by yeast extracts. In our experiments, however, $\alpha$ glycerophosphate did not enhance acetate uptake by washed $M$. laidlawii. Furthermore, the small amount of labelled pyruvate incorporated by the cells was not found in the glycerol moiety of the lipids.

Inhibition of acetate uptake by propionate and butyrate may be explained either by (a) competitive inhibition of the transport system responsible for the transfer of external acetate into the cells; or $(b)$ inhibition of the utilization of acetate for lipid biosynthesis. The finding that both propionate and butyrate inhibited activation of acetate by acetokinase indicates that their inhibitory effect was at least partially attributable to the inhibition of acetate incorporation into the lipids. Similarly in brain cells propionate and butyrate have been found to block acetate metabolism to a greater extent than its transport (Quastel, 1965).

Inhibition of acetate uptake by iodoacetate may be simply explained by inhibition of glycolysis, thus cutting off the energy supply required for acetate incorporation. However, the very low concentrations at which this inhibitor was still effective point to a more specific effect, probably on the transport system of acetate.

This research was financed in part by grant no. PG-Is-174 made by the United States Department of Agriculture under P.L. 480.

This work forms part of an investigation made by $\mathbf{S}$. Rottem in partial fulfilment of the requirements for the Ph.D. degree at the Hebrew University, Jerusalem.

\section{REFERENCES}

Ansell, G. B. \& Hawthorne, J. N. (1964). Phospholipids, p. 43. New York: Elsevier Publishing Co. CAstrejon-Diez, J., Fisher, T. N. \& Fisher, E. Jun. (1962). Acetokinase reaction in several pleuropneumonia-like organisms. Biochem. biophys. Res. Commun. 9, 416.

Folch, J., Lees, M. \& SlOANe-Stanley, G. H. (1957). A simple method for the isolation and purification of total lipids from animal tissues. J. biol. Chem. 226, 497.

Freundt, E. A. (1958). The Mycoplasmataceae. (The Pleuropneumonia Group of Organisms.) Morphology, Biology and Taxonomy. Copenhagen: Munksgaard.

Kates, M. (1964). Simplified procedure for hydrolysis or methanolysis of lipids. J. Lipid Res. 5, 132.

Lowry, O. H., Rosebrough, N. J., Farr, A. L. \& Randall, R. J. (1951). Protein measurement with the folin phenol reagent. J. biol. Chem. 193, 265.

Neimark, H. C. \& Pickett, M. J. (1959). Products of glucose metabolism by pleuropneumonia-like organisms. Ann. N.Y. Acad. Sci. 79, 531.

Quastel, J. H. (1965). Molecular transport at cell membranes. Proc. Roy. Soc. B 163, 169.

RAZIN, S. (1963). Osmotic lysis of Mycoplasma. J. gen. Microbiol. 33, 471.

Razin, S. (1967). The cell membrane of Mycoplasma. Ann. N.Y. Acad. Sci. (in the Press).

Razin, S. \& Cleverdon, R. C. (1965). Carotenoids and cholesterol in membranes of Mycoplasma laidlawii. J. gen. Microbiol. 41, 409.

RAzIN, S. \& CoHEN, A. (1963). Nutritional requirements and metabolism of Mycoplasma laidlawii. J. gen. Microbiol. 30, 141.

RAzIN, S. \& Cosenza, B. J. (1966). Growth phases of Mycoplasma in liquid media observed with phase-contrast microscope. J. Bact. $91,858$.

Razin, S. \& Rottem, S. (1963). Fatty acid requirements of Mycoplasma laidlawii. J. gen. Microbiol.33, 459.

RAZIN, S., KNYSZYNSKI, A. \& LIFShITZ, Y. (1964). Nucleases of Mycoplasma. J. gen. Microbiol. 36, 323.

Rodwell, A. W. (1967). The nutrition and metabolism of Mycoplasma: progress and problems. Ann. N.Y. Acad. Sci. (in the Press). 
Rodwell, A. W. \& Aвbot A. (1961). The function of glycerol, cholesterol and long-chain fatty acids in the nutrition of Mycoplasma mycoides. J. gen. Microbiol. 25, 201.

Rose, I. A. (1955), Acetate kinase of bacteria (acetokinase). Meth. Enzymol. 1, 591.

RotTEM, S. \& RAZIN, S. (1964). Lipase activity of Mycoplasma. J. gen. Microbiol. 37, 123.

RotTem, S. \& Razin, S. (1966). Adenosine triphosphatase activity of Mycoplasma. J. Bact. $92,714$.

SMITH, P. F. (1963). The carotenoid pigments of Mycoplasma. J. gen. Microbiol. 32, 307.

Sмith, P. F. (1964). Comparative physiology of pleuropneumonia-like and L type organisms. Bact. Rev. $28,97$.

Smith, P. F. \& HenRIKson, C. V. (1965). Comparative biosynthesis of mevalonic acid by Mycoplasma. J. Bact. 89, 146.

Stadtman, E. R. (1955). Phosphotransacetylase from Clostridium kluyveri. Meth. Enzymol. 1, 596.

Tourtellotte, M. E., Morowitz, H. J. \& Kasimer, P. (1964). Defined medium for Mycoplasma laidlawii. J. Bact. 88, 11.

White, D. \& KLEIN, H. P. (1966). Effect of $\alpha$-glycerophosphate and of palmityl-coenzyme A on lipid synthesis in yeast extract. J. Bact. 91, 1218. 